\title{
JCNaR
}

\section{Improving Porosity of Glycerol-plated Silica from Rice Husk Silica}

\author{
Saur Lumbanraja ${ }^{1}$, Hamonangan Nainggolan ${ }^{1}$, Cita Sitohang ${ }^{1}$ \\ ${ }^{1}$ Department of Chemistry FMIPA University of North Sumatra, Jalan Bioteknologi No. 01 Kampus \\ USU Medan 20155
}

\begin{abstract}
Research on the increasing pore size of rice husk silica with the addition of glycerol as a template has been done. Sodium silicate obtained from rice husk can be extracted with sodium hydroxide. The resulting sodium silicate is then added to the glycerol and followed by precipitation using hydrochloric acid to obtain silica. The obtained results were calcined at $600^{\circ} \mathrm{C}$. The resulting material analised by FT-IR, XRD and BET. The FTIR data shows an asymmetric Si-O-Si absorption peak at wave number $1067 \mathrm{~cm}^{-1}$ and a symmetrical Si-O-Si peak absorption at $806.77 \mathrm{~cm}^{-1}$ wave number. Diffractogram XRD also shows a widening peak in the area of 22.820 that the silica is amorphous. The result of adsorption of nitrogen desorption of silica isotherm indicated Type IV isotherm adsorption which was characteristic of mesoporous material and obtained the size distribution of $9.2 \mathrm{~nm}$ and the pore volume was $0.002850 \mathrm{cc} / \mathrm{g}$ and the surface area of silica was $80.38 \mathrm{~m}^{2} / \mathrm{g}$.
\end{abstract}

Keyword: Rice Husk, Silica, Template, Glycerol.

Received 30 July 2019 | Revised 26 August 2019| Accepted 29 August 2019

\section{Introduction}

Rice husk has a high silica content at $18-22 \%$ and rice husk ash has a silica content of $88.32 \%$ (Luh, 1991). Rice husk silica can be isolated by a simple combustion method which could eliminate the components of organic compounds (Luh, 1991). Siburian (2015) has conducted a research on silica purity by using temperature variations of $800^{\circ} \mathrm{C}, 850^{\circ} \mathrm{C}$ and $900^{\circ} \mathrm{C}$, and obtained purer silica during combustion at $900^{\circ} \mathrm{C}$. This will increase the added value of rice husk. Silica is widely used in industrial fields, for example in making glass, making ceramics, catalysts and adsorbents (Kirk-Othmer, 1984).

Ryu (2006) had also prepared amorphous silica by oxidation of silicon.

\footnotetext{
*Corresponding author at: Department of Chemistry FMIPA University of North Sumatra, Jalan Bioteknologi No. 01 Kampus USU Medan 20155

E-mail address: lumbanrajasaur@yahoo.com
} 
Journal of Chemical Natural Resources Vol. 01, No. 02, 2019

The pore size of silica can be modified by adding carbon-containing templates (Sukalyan, 2008). The synthesis of mesoporous silica from rice husk has been carried out by Siburian (2015) with the calcination method and concluded that the calcination results of $900 \mathrm{oC}$ obtained a pore size of $5 \mathrm{~nm}$.

Synthesis of mesoporous material is conducted by combining inorganic components as mesopore material and organic components as templates in the form of surfactants then calcination to remove organic components (Larsen, 2000). Templates are used as molds (auxiliaries and guides) in pore formation, where the primary colloidal particles will fill the gaps between the template arrangements, so when the template is removed from the silica particles, hollow particles will form (Yang, 2011).

Several approaches to synthesize porous particles have been reported, mostly by using organic templates. Savitri (2012) conducted a study on the differences in ZSM Alkali treatment (Zeolite Socony Mobil) and porous ZSM. The result was ZSM with the tetrapropylammonium hydroxide $(\mathrm{TPAOH})$ template produced pore sizes from micropore to mesoporous and uniform. Template compounds can be removed by calcination. The results of the study (Sriwahyuni, 2013) showed that the calcination method was found to be able to eliminate the PEG compound (polyethylene glycol) which served as a better template than the solvothermal extraction method. From the results of the study, the addition of PEG had an effect on the addition of the size of the silica pore diameter of $3.84 \mathrm{~nm}$.

One of the organic components that can be used as a template is glycerol. Glycerol is an organic compound in the form of fluid, easily obtained, has a polar - $\mathrm{OH}$ group, when it is combusted it will evaporate easily.

In addition, porosity is one of the factors that influence the physical interaction of material with gases or liquids (Rouquerol et al., 1994). Silica is widely used for various purposes according to the purity, surface area and silica pore size, for example porous silica can be applied as a catalyst support (Zawrah, 2009).

From the description above, researchers are interested in conducting research on increasing the pore size of rice husks silica by using glycerol as a template. In this case the rice husk ash will be purified first and then $\mathrm{NaOH}$ is added to form sodium silicate. This sodium silicate is added with glycerol and $\mathrm{HCl}$ to form a sol gel process. The results obtained are then calcinated in a furnace and formed crystalline silica solids. 


\section{Method}

\subsection{Research Procedure}

\subsubsection{Rice Husk Calcination}

$100 \mathrm{~g}$ of rice husk is washed and dried. Rice husk was filtered and calcinated at $900 \mathrm{oC}$ for 6 hours.

\subsubsection{Creating Sodium Silicate Solution}

10 grams of rice husk ash was dispersed with $60 \mathrm{~mL}$ of distilled water then added with $\mathrm{HCl}$ at pH 1 then stirred for 2 hours and filtered. The precipitation obtained was washed with distilled water then $3 \mathrm{~N} \mathrm{NaOH}$ was added as much as $60 \mathrm{~mL}$ then boiled and stirred for 1 hour then filtered using whatman filter paper No.42. The precipitation result is washed with hot water. The resulting filtrate is washed as a sodium silicate solution.

\subsubsection{Formation of Silica with Glycerol template}

The filtrate as a result of washing was added with glycerol as much as 3 grams then added $1 \mathrm{~N}$ $\mathrm{HCl}$ until it reached $\mathrm{pH} 7$ then left for 18 hours. The precipitation result was washed several times using distilled water and then centrifuged. The obtained silica is heated in an oven at $120 \mathrm{oC}$ for 2 hours then washed with distilled water. The results obtained were calcinated in the furnace at $600 \mathrm{oC}$. The results obtained were characterized using FT-IR, XRD, and BET analysis.

\section{Result and Discussion}

\subsection{Rice Husk Calcination}

Rice husks silica can be isolated by calcination methods in rice husks such as lignin and cellulose. But the combustion carried out must have a controlled temperature (Harsono, 2002). 100 grams of rice husk is calcinated in the furnace at $900^{\circ} \mathrm{C}$. The results of the calcination of rice husks are white.

The rice husk ash obtained still contains other metal oxides in the form of $\mathrm{Al}_{2} \mathrm{O}_{3}, \mathrm{Fe}_{2} \mathrm{O}_{3}, \mathrm{CaO}$, $\mathrm{MgO}$, dan $\mathrm{K} 2 \mathrm{O}$ (Habeeb, 2009). To remove metal oxides $\mathrm{HCl}$ at pH1 is added $\mathrm{f}$ (Chakraverty, 1988).

Afterwards, $\mathrm{NaOH}$ is added to the rice husk ash that has been washed with water. $\mathrm{NaOH}$ was chosen on the grounds that silica can react with bases, especially with strong bases, such as 
alkaline hydroxide. Commercially, silica is made by mixing a solution of sodium silicate with a mineral acid (Svehla, 1985).

The $\mathrm{NaOH}$ compound is an alkaline compound, when dissolved in water separates and releases $\mathrm{OH}-$ like reactions:

$$
\mathrm{NaOH}(\mathrm{s})+\mathrm{H}_{2} \mathrm{O} \rightarrow \mathrm{Na}+(\mathrm{aq})+\mathrm{OH}-(\mathrm{aq})
$$

In silica ( $\mathrm{SiO} 2)$, the high electronegativity of $\mathrm{O}$ atoms causes $\mathrm{Si}$ to be more electropositive and to form intermediates $[\mathrm{SiO} 2 \mathrm{OH}]$ - which are unstable, here dehydrogenation will occur and the second hydroxyl ion will bound to hydrogen to form water molecules. Two $\mathrm{Na}+$ ions will balance the negative charge formed and interact with $\mathrm{SiO} 32$ ions to form sodium silicate (Mujiyanti, 2010). The reactions that occur are as follows.

$$
\mathrm{SiO}_{2}(\mathrm{~s})+2 \mathrm{NaOH}(\mathrm{aq}) \quad \rightarrow \mathrm{Na}_{2} \mathrm{SiO}_{3}(\mathrm{aq})+\mathrm{H}_{2} \mathrm{O}(\mathrm{l})
$$

\subsection{Formation of Glycerol with Silica Template}

The sodium silicate solution which has been obtained is then added with glycerol. Glycerol is used as a template because it has an extremely polar group which has 3 groups of $-0 \mathrm{H}$. Glycerol in this case acts as a pore printer (template). Silica sodium has pores and glycerol will enter the pores.

Afterwards, the results obtained were added with $1 \mathrm{~N} \mathrm{HCl}$ until it reached $\mathrm{pH}$. The addition of $\mathrm{HCl}$ to sodium silicate solution caused the exchange of $\mathrm{Na}+$ ions with $\mathrm{H}+$ to produce a gelshaped solid that finally separated particles from silica bound to water molecules namely silica hydrosol or silicic acid $\left(\mathrm{H}_{2} \mathrm{SiO}_{3}\right)$.

The reactions that occur are as follows:

$$
\mathrm{Na}_{2} \mathrm{SiO}_{3}(\mathrm{aq})+2 \mathrm{HCl}(\mathrm{aq}) \rightarrow \mathrm{SiO}_{2} \cdot \mathrm{H}_{2} \mathrm{O}(\mathrm{l})+\mathrm{NaCl}(\mathrm{aq})
$$

The material was soaked for 18 hours with the aim of growing crystals. The formed sol-gel was washed with distilled water to remove the salt formed in the reaction. After it was centrifuged, the precipitation was dried in an oven at $120 \mathrm{oC}$ for 2 hours and washed with hot distilled water to remove excess acid. Heating at $120 \mathrm{oC}$ resulted in dehydration of silica hydrosol so that silica gel $\left(\mathrm{SiO}_{2} \cdot \mathrm{H}_{2} \mathrm{O}\right)$ was formed and then refined to obtain silica powder (Lubis, 2009).

After that, it was calcinated again at $600^{\circ} \mathrm{C}$ to remove the glycerol compound contained in the solid form. In this case, it was observed that glycerol will leave the pore and form larger and white pores. The interaction between silica and glycerol can be seen in Figure 3.1. 


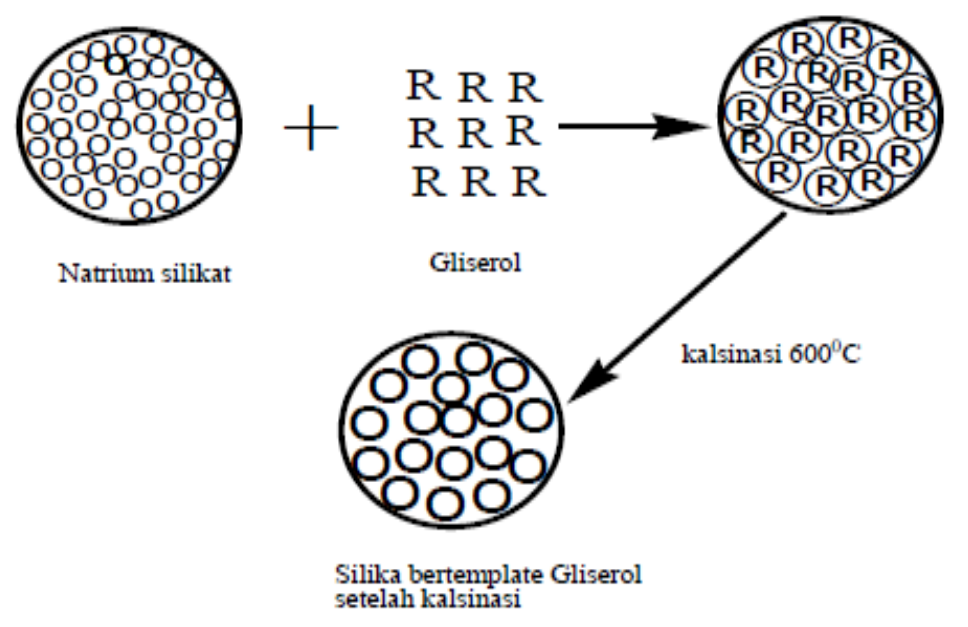

Figure 3.1 Interaction of Silica from Sodium Silicate with Glycerol

\subsection{Characterization of Silica with Glycerol Template}

\subsubsection{FT-IR Spectrum}

FTIR analysis is a tool used for quantitative analysis based on existing functional groups using standards.

The FT-IR results on silica obtained are shown in Figure 3.2 below.

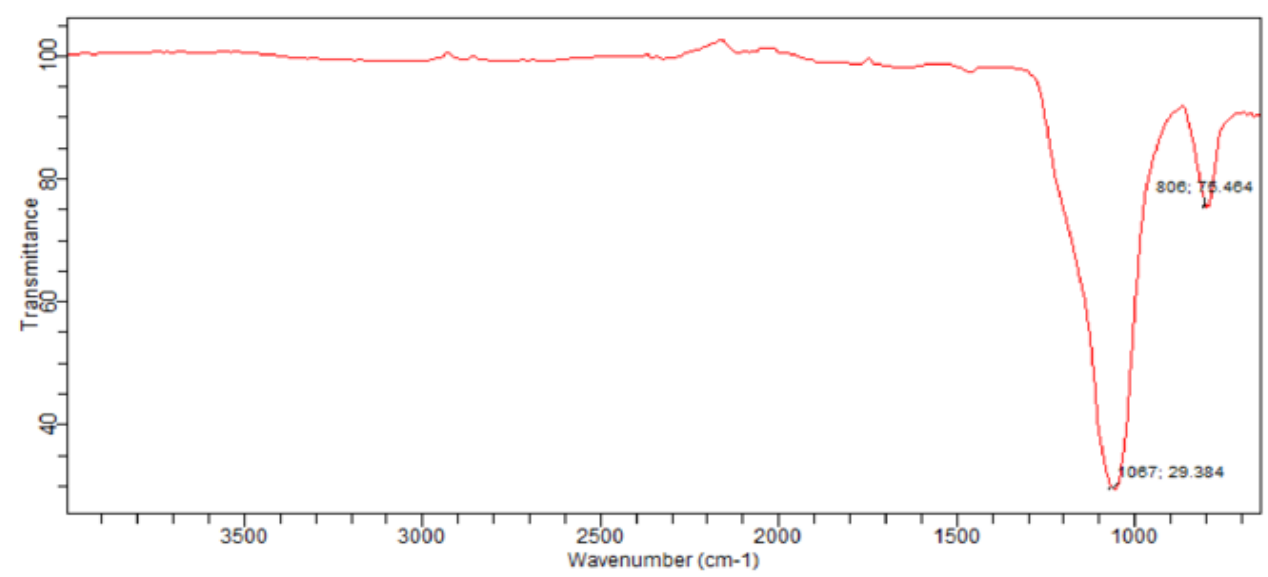

Figure 3.2 Spectrum of FT-IR Silica with Glycerol Template

The FT-IR spectrum in figure 3.2 shows the characteristics of silica with a template. The absorption peak at wave number $1067.29 \mathrm{~cm}-1$ shows the presence of an asymmetrical Si-O-Si group and at the peak of wave number $806.75 \mathrm{~cm}-1$ indicates the presence of a $\mathrm{Si}-\mathrm{O}-\mathrm{Si}$ 
symmetrical group. The difference in absorption between the Si-O-Si asymmetrical group and the $\mathrm{Si}-\mathrm{O}-\mathrm{Si}$ symmetrical group is due to the different vibrations in $\mathrm{Si}-\mathrm{O}-\mathrm{Si}$.

Figure 3.3 displayed FT-IR silica spectrum without a template. This can be used as a comparison between the FT-IR spectrum of silica with glycerol template (Figure 3.2) and FTIR silica spectrum without a template.

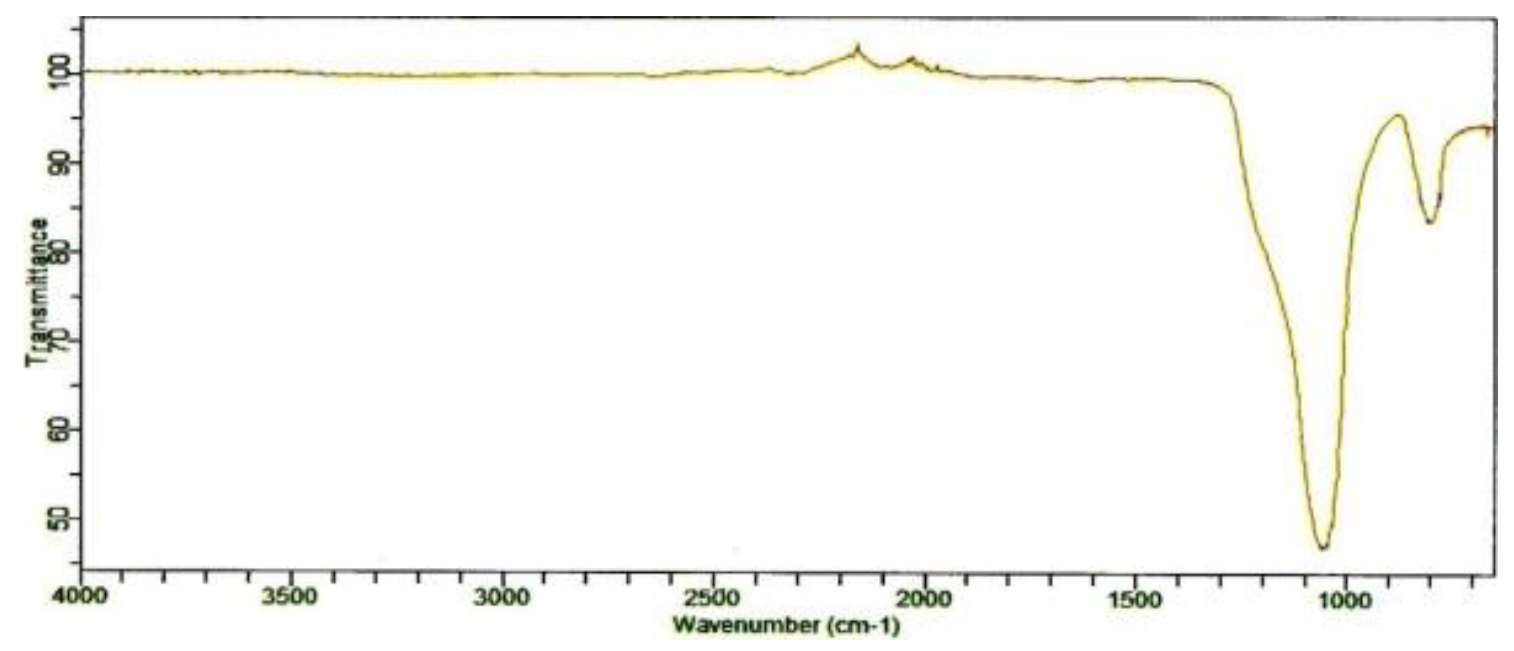

Figure 3.3. Silica without template

The results of FTIR silica spectrum analysis without template displayed the absorption peak at wave number $1056 \mathrm{~cm}-1$; which showed the presence of an asymmetric Si-O-Si group and at the peak of wave number $806 \mathrm{~cm}-1$ showed the presence of a Si-O-Si symmetrical group. Glycerol uptake was at a wavelength of $3400 \mathrm{~cm}-1-3600 \mathrm{~cm}-1$ and in FT-IR silica data without template and FT-IR spectrum glycerol with template did not appear. The peak showed glycerol and water contained previously in the combustion material in the furnace. Therefore, the calcination method is able to remove glycerol compounds. The results of the characterization of silica with glycerol template are in accordance with the study reported by Silverstein, (1986); Siburian (2015).

\subsubsection{X-ray diffraction}

$\mathrm{X}$-ray diffraction method (XRD) is an analysis method that can provide crystallite material information qualitatively. The diffraction patterns obtained from silica with templates are shown in Figure 3.4 


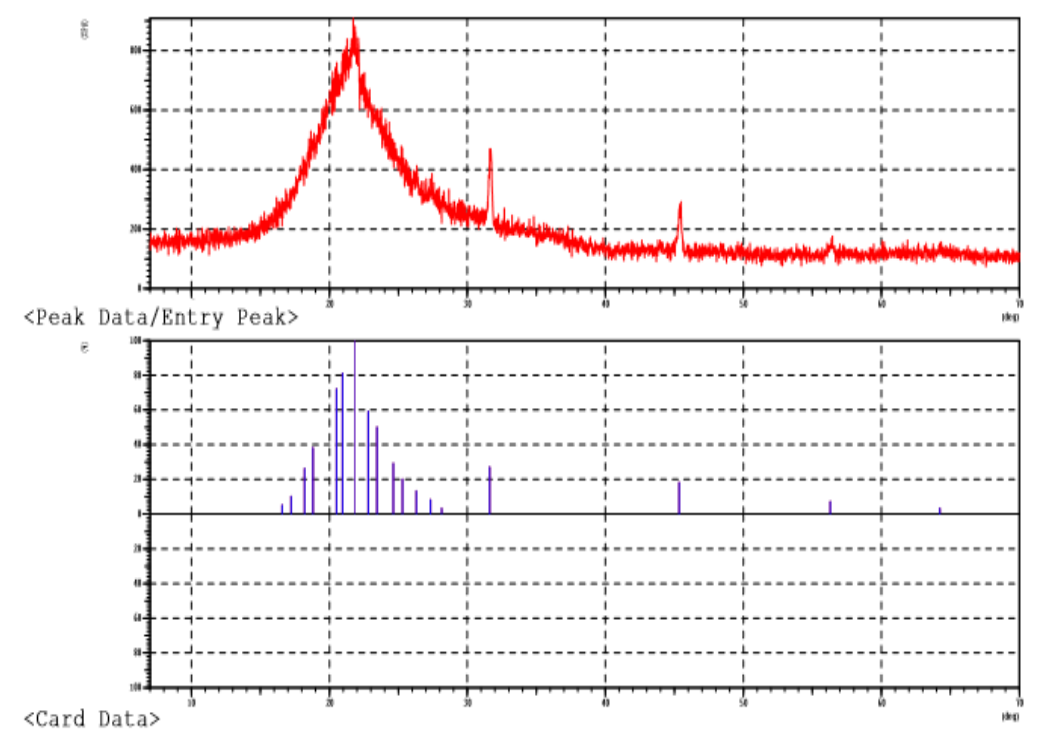

Figure 3.4 Diffractogram XRD Silica with Glycerol Template

The XRD diffraction pattern data shows the peak at $2 \theta=22.80$ o; $2 \theta=31.60$ and $2 \theta=45.34$ o. In the powder's diffractogram, only one high peak appears, i.e. peak $2 \theta=22.80 \mathrm{o}$, while other peaks do not appear as high peaks, this is due to the low crystallinity of the sample, resulting from a low calcination temperature, so that only one wide peak appears. According to Kalaphaty (2000) the shape of a wide peak with a peak center around $2 \theta=21-22$ o indicates that silica is amorphous.

\subsubsection{BET Test Results}

The graph of adsorption-desorption of nitrogen isotherm is the result of BET silica characterization. Nitrogen isotherm adsorption is done to measure the pore size distribution of silica material. The graph curve of isotherm adsorption with the BJH method can be seen in Figure 3.5 


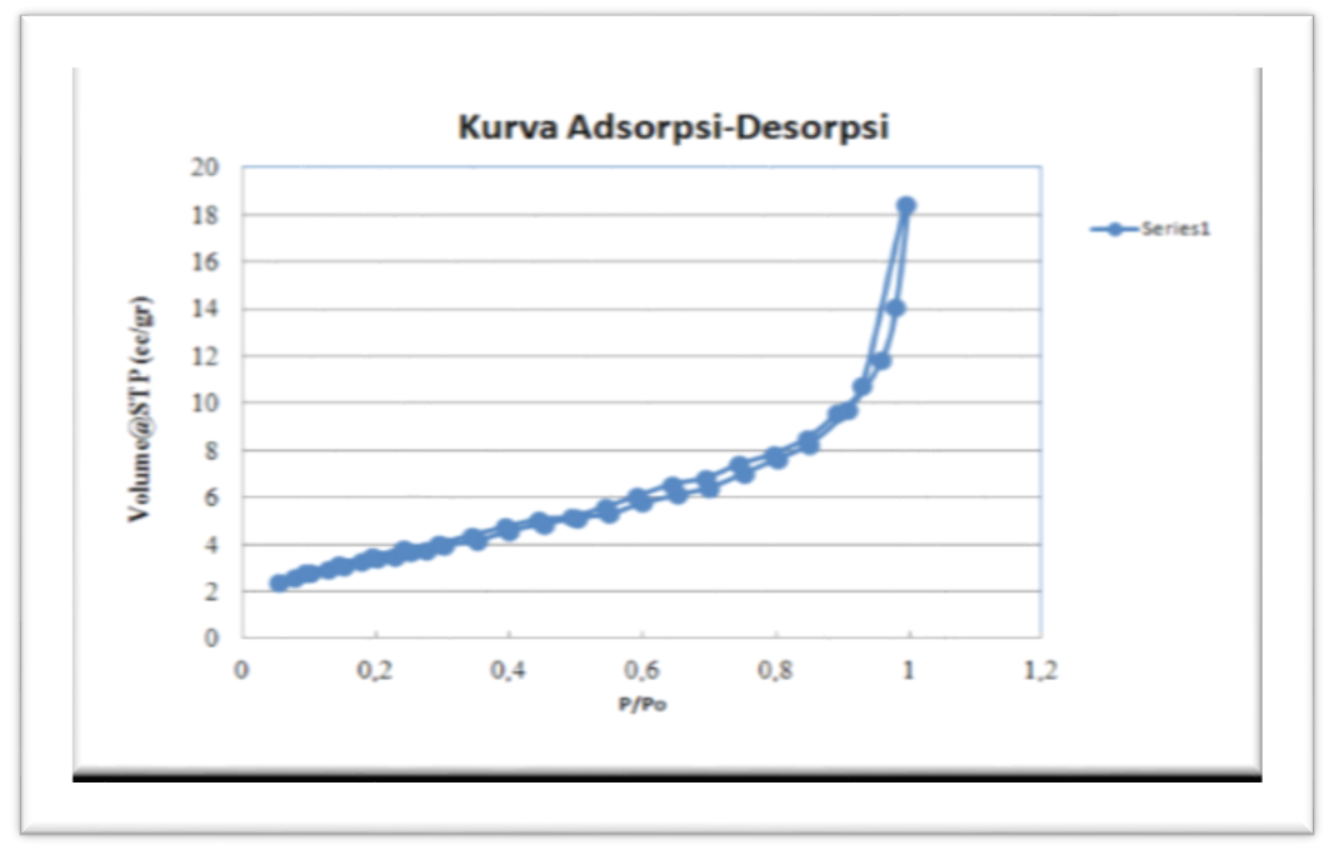

Figure 3.5 Adsorption-Desorption Graph of Isotherm Nitrogen

According to IUPAC (1985), Figure 3.5 graph of silica adsorption-desorption with the addition of glycerol is included in the type IV graph. From the graph of nitrogen isotherm adsorption from silica followed by capillary condensation at a relative pressure ( $\mathrm{p} / \mathrm{po}$ ) between 0.6-0.9 indicates the presence of multilayer formation. Capillary condensation shows the difference in pressure produced between the adsorption and desorption processes. Type IV shows that porous material subjected to nitrogen gas is included in the mesoporous category (Quercia, 2013).

Templates are used as molds (auxiliaries and directors) in pore formation, where particles will fill the gaps between the templates arrangement, thus when templates are removed from silica particles, hollow particles will form (Yang, 2011).

To find out the pore size distribution, the BJH method is used and can be seen in Figure 3.6

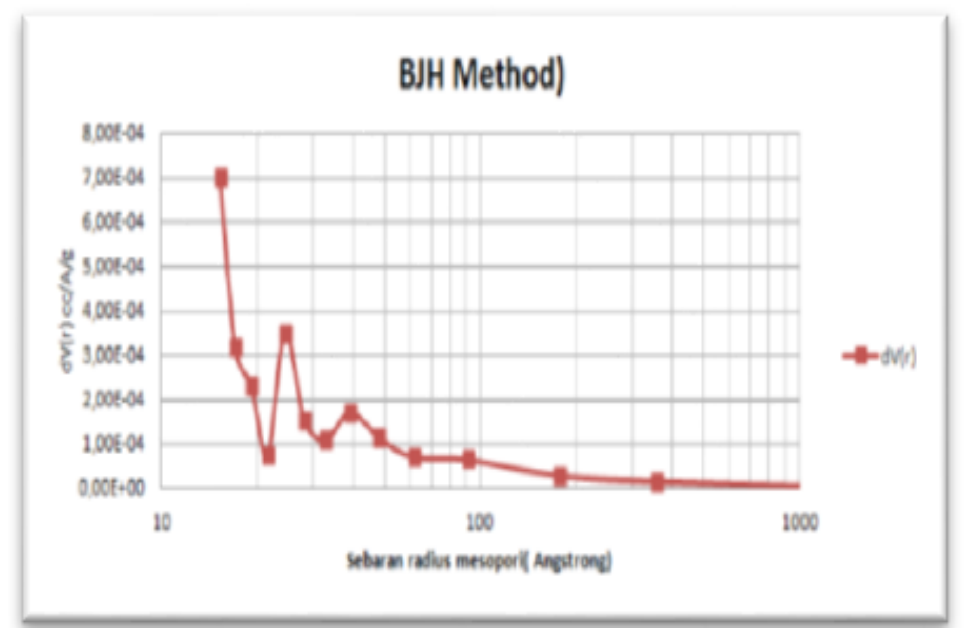

Figure 3.6 Glycerol with Silica Template Pore Size Distribution Chart 
The distribution graph of the particle pore size shows that the average size of the pore radius based on the calculation obtained the radius of the pore size is $4.6 \mathrm{~nm}$ or if converted into pore size diameter, it reaches $92 \AA$ or $9.2 \mathrm{~nm}$. In this case, the addition of glycerol as a template resulted in the formed pore size falls into the mesoporous category. Siburian (2015) conducted a study on the synthesis of mesoporous silica and the silica pore size obtained without template reached $5 \mathrm{~nm}$. Addition of glycerol in this study obtained a larger pore size. From the aforementioned data, it can also be seen the pore volume of silica with the addition of glycerol as a template. From the results of the study, the average pore volume was $0.00285 \mathrm{cc} / \mathrm{g}$ and also the surface area of silica was $80.38 \mathrm{~m} 2 / \mathrm{g}$. Therefore, the addition of the template will affect the pore size, pore volume and also the surface area of the silica produced.

\section{Conclusion}

The results of the research that have been done can be concluded as follows:

1. Adding glycerol as a template can increase the pore size of silica. This is indicated by an increase in silica's porosity from $5 \mathrm{~nm}$ to $9.2 \mathrm{~nm}$. The results of adsorption-desorption isotherm nitrogen on the addition of glycerol as a template show the silica pore included in Type IV and the radius of pore size obtained: $9.2 \mathrm{~nm}$, pore volume: $0.00285 \mathrm{o} \mathrm{cc} / \mathrm{g}$ and silica surface area: $80.38 \mathrm{~m} 2 / \mathrm{g}$.

2. Analysis of silica with glycerol template by using FT-IR shows that the calcination method can remove the glycerol group. This is proven by the peak of Si-O-Si asymmetric absorption at wave number $1067 \mathrm{~cm}-1$ and symmetrical absorption peak at Si-O-Si wave number $806.77 \mathrm{~cm}-1$. The XRD analysis results indicate a widening peak at 22.80 . This proves that the obtained silica is amorphous.

\section{References}

[1] Chakraverty, A., Mishra, P., and Banerjee ,D. 1988. Investigation of Combustion of Raw and Acid-Leached Rice Husk for Production of Pure Amorphous White Silica. Journal of Materials Science. Vol. 23, pp. 21-24. 8.

[2] Habeeb.2009. Study on Properties of Rice Husk Ash and Its Use as Cement Replacement Material. Journal of Materials. 13:185-190.

[3] Harsono, H. 2002. Pembuatan Silika Amorf dari Limbah Sekam Padi. Jurnal Ilmu Dasar.

[4] Kalapathy, U., Proctor, A., and Shultz, J., (2000), A simple method for production of pure silica from rice hull ash, Bioresource Technology, 73, pp. 257-262.

[5] Kirk-Otmer. 1967. Encyclopedia of Chemical Tecgnology. Interscience Publisher. New York. 
[6] Larsen, R.B., Polve,,M., Juve,G., 2000. Granite pegmatite quartz from Evjelveland, Trace Element Chemostry and Implications for the Formation of High purity quartz. Norges Geologiske Undersogelse Bulletin 436,57-65.

[7] Lubis, S. 2009. Preparasi Katalis Cu/ Silika Gel dari Kristobalit Alam Sabang serta Uji Aktivitasnya pada Reaksi Dehidrogenasi Etanol. Jurnal Rekayasa Kimia dan Lingkungan vol.7 no.1 (29-35).

[8] Luh, B.S.1991. Rice Utilization. Second Edition. Van Nostrand Reinhold. USA Eliasson, A. 2004. Starch in Food : Structure, Function and Application. Woodhead Publishing Limited: North America.

[9] Mujiyanti, Nuryono, Kunarti. 2010. Sintesis dan karakterisasi Silika Gel dari Abu Sekam Padi yang diimobilisasi dengan 3-(Trimetoksisilil)-1-propantiol. Jurnal Sains vol.4 no.2 (150-167).

[10] Quercia G., A. Lazaro, J.W. Geus, dan H.J.H. Brouwers. 2013. Characterization of Morphology and Texture Of Several Amorphous Nano-Silica Particles Used in Concrete. Cement \& Concrete Composites. Vol. 44: hal 77-92.

[11] Rouquerol, J., Avnir, W. Fairbridge, H. Everett, j. H. Haynes, n. Pernicone, j. D. F. Ramsay k. S. W. Sing dan k. K. Unger. 1994. International Union of Pure and Applied Chemistry (Iupac), Recommendations for the Characterization of Porous Solids . Journal of Pure \& Appl. Chern., Vol. 66, No. 8, pp. 1739-1758, 1994.

[12] Ryu, S.-R., J. Non-Cryst. Solids, 352, 3929-35, 2006.

[13] Savitri. (2012). Sintesis dan Karakterisassi Zeolit ZSM 5-Mesopori dengan metode desilikasi dan studi awal katalis oksidasi metana.UI. Jakarta.

[14] Siburian, M.S. 2015. Sintesis dan Karakterisasi Mesopori Silika dari Sekam Padi dengan Metode Kalsinasi. USU.

[15] Silverstein, R.M., Bassler, G.C. and Morrill, T.C. 1986. Spectrometric Identification of Organic Compound. John Wiley and Sons. New York.

[16] Sriwahyuni, 2003. Sintesis Silika Tersulfonasi Dari Waterglass Dengan Templat PEG Sebagai Katalis Asam Padat dalam Pembuatan Pelumas dari Minyak Nabati. ITS. Surabaya.

[17] Sukalyan Dash, Soumyashri Mishra, Sabita Patel, dan Bijay K.Mishra (2008), Organically Modified Silica: synthesis and Application due to Its Surface Interction with Organic molecules,Advance in Colloid and Interface Science, Volume XX, Burla, Elsevier.

[18] Svehla G. 1985. Vogel Bagian II Buku Teks Analisis Anorganik Kualitatif Makro dan Semimikro Edisi ke lima. Jakarta : PT. Kalman Media Pustaka.

[19] Yang X, S Liao \& Z Liang (2011). Gelatin-assisted templateing route to synthesize sponge-like meso- porous silica with bimodal porosity and lysozyme adsorption behavior. Microporous \& Mesoporous Materials 143, 263-268.

[20] Zawrah, M. F. and El-Kheshen, A. A., 2009. Facile and Economics Synthesis of Silica Nanoparticles. Journal of Ovonic Reasearch. 129-133 